\begin{tabular}{|l|l|l||}
\hline \multicolumn{2}{|c|}{ PublisherInfo } \\
\hline \hline PublisherName & $:$ & BioMed Central \\
\hline \hline PublisherLocation & $:$ & London \\
\hline \hline PublisherImprintName & $:$ & BioMed Central \\
\hline \hline
\end{tabular}

\title{
Not much in common
}

\begin{tabular}{|l|l|l||}
\hline \multicolumn{2}{|c|}{ ArticleInfo } \\
\hline \hline ArticleID & $:$ & 4190 \\
\hline \hline ArticleDOI & $:$ & $10.1186 /$ gb-spotlight-20010830-01 \\
\hline \hline ArticleCitationID & $:$ & spotlight-20010830-01 \\
\hline \hline ArticleSequenceNumber & $:$ & 261 \\
\hline \hline ArticleCategory & $:$ & Research news \\
\hline \hline ArticleFirstPage & $:$ & 1 \\
\hline \hline ArticleLastPage & $:$ & 2 \\
\hline \hline & & RegistrationDate : 2001-08-30 \\
ArticleHistory & $:$ & OnlineDate \\
\hline \hline ArticleCopyright & $:$ & BioMed Central Ltd2001 \\
\hline \hline ArticleGrants & $:$ & \\
\hline \hline ArticleContext & $:$ & 130592211 \\
\hline \hline
\end{tabular}




\section{Jonathan B Weitzman}

Email: jonathanweitzman@hotmail.com

The two groups who sequenced the human genome agreed on one thing - that there are fewer genes than everyone originally thought. Both groups estimated around 30,000 genes, using un-precise prediction methods. In the August 24 Cell, John Hogenesch and colleagues, at The Genomics Institute of the Novartis Research Foundation in California, compared the two sets of predicted genes to see how much they agree (Cell 2001, 106:413-415). They compared the transcriptomes of the Celera (39,114 genes) and Ensembl (29,691 genes) draft sequences with each other, and with the curated Refseq set of genes. First, they showed that the Celera and Ensembl sets contained most of the known genes. But, of the 31,098 potential novel transcripts, $80 \%$ were predicted by only one group or the other, but not both. Hogenesch et al. then performed oligonucleotide microarray analysis to examine the expression profile of these potential novel transcripts. They found that $80 \%$ of known genes and $80 \%$ of novel genes could be detected in at least one of the tissue samples analysed. These results highlight the limitations of current computational methods to predict novel genes and the value of using expression profiling to help uncover the complete transcriptome.

\section{References}

1. Cell, [http://www.cell.com]

2. The Genomics Institute of the Novartis Research Foundation , [http://www.gnf.org/]

3. Celera, [http://www.celera.com]

4. Ensembl, [http://www.ensembl.org]

5. Refseq, [http://www.ncbi.nlm.nih.gov/LocusLink/refseq.html]

This PDF file was created after publication. 